\title{
Perbandingan Penggunaan Panel Surya dan Turbin Angin dalam Implementasi Energi Baru Terbarukan (EBT) di Lingkungan Universitas Pertamina
}

\section{Comparison of Solar Panel and Wind Turbine as New and Renewable Energy Sources in Pertamina University}

\author{
RIESTIYA ZAIN FADILLAH, ADHYTIA IHZA MAHENDRA, MUHAMAD BENANDO BANDA \\ PANGESTU, AFRIANSYAH, AHMAD FAUZAN RAHMAN, ALZAHID MUHASABAH, MEREDITA \\ SUSANTY, ERWIN SETIAWAN
}

Universitas Pertamina, Simprug, Jl. Teuku Nyak Arief, RT.7/RW.8, Grogol Selatan, Kebayoran Lama, Kota Jakarta Selatan, Daerah Khusus Ibukota Jakarta 12220

Email: riestiyazainf@gmail.com

\begin{abstract}
Solar panels and small wind turbines in urban areas could become an alternative solution for Indonesia's energy availability and security. However, its implementation in urban areas is still facing some challenges due to other buildings' presence, which are a barrier to get the optimum sources. It is necessary to find the most optimal implementation. The determinant parameters are economic feasibility, maintenance costs, and carbon emissions reduced from each new and renewable energy (NRE). The analysis in this study employs the literature study and quantitative analysis methods. In this research, the NRE installation in Pertamina University Building represents office buildings in an urban area located in the tropical region. The results show that solar panels have higher efficiency and effectiveness than wind turbines because of the frequency of wind turbines' failure.
\end{abstract}

Keywords: wind turbine, solar panel, new and renewable energy, effectiveness, efficiency

\begin{abstract}
ABSTRAK
Instalasi panel surya dan turbin angin skala kecil di area perkotaan bisa menjadi salah satu solusi alternatif untuk mendukung ketersediaan dan ketahanan energi nasional. Dalam penerapannya di area perkotaan berbagai sumber EBT memiliki tantangan tersendiri seperti keberadaan bangunan lain yang menjadi penghalang pembangkit mendapatkan sumber energi maksimal, sehingga perlu dilakukan perbandingan dan analisis implementasi yang paling optimal untuk diterapkan. Parameter yang digunakan sebagai penentu adalah economic feasibility, biaya perawatan dan emisi karbon yang dikurangi dengan penggunaan EBT. Analisis dilakukan dengan metode studi literatur dan analisis kuantitatif. Dalam penelitian ini instalasi EBT di Gedung Universitas Pertamina menjadi sample yang mewakili bangunan perkantoran di area perkotaan daerah tropis. Hasil analisis menunjukkan bahwa panel surya memiliki tingkat efisiensi dan efektivitas yang lebih tinggi dibandingkan turbin angin yang disebabkan frekuensi kerusakan pada pembangkit listrik bertenaga angin.
\end{abstract}

Kata kunci: turbin angin, panel surya, energi baru terbarukan, efektivitas, efisiensi

\section{PENDAhULUAN}

\subsection{Latar Belakang}

Ketersedian dan ketahanan energi sangat penting bagi suatu negara karena energi merupakan komponen utama dalam memproduksi barang dan jasa. Hal ini dapat terlaksana bilamana melaksanakan dua pendekatan sekaligus dengan baik yakni diversifikasi energi dan konservasi energi. Pemerintah Indonesia menetapkan target untuk energi baru dan terbarukan (EBT) diperkirakan $23 \%$ pada 2025 dan $31 \%$ pada $2050^{(1)}$, di mana pada 2017 , EBT hanya sekitar $12,5 \%{ }^{(2)}$. Potensi EBT di Indonesia untuk pembangkit listrik cukup besar (442 GW) dengan jenis energi surya, air, dan angin sebagai sumber terbesar.

Kondisi geografis dan iklim menentukan campuran optimal EBT di suatu wilayah ${ }^{(3,4)}$. Meskipun energi surya memiliki potensi yang besar di Indonesia(5), pemanfaatannya baru $0,05 \%$ karena investasi yang cukup mahal dan masalah pembebasan lahan ${ }^{(6)}$. Masalah serupa juga dihadapi sumber energi air dan angin. Ditambah lagi keadaan geografis Indonesia dimana angin lebih lemah dibandingkan di Eropa dan arah angin yang lebih sering berubah membuat teknologi kincir berukuran besar tidak cocok untuk digunakan di semua area di Indonesia ${ }^{(7)}$. Alternatif dari permasalahan- 
permasalahan tersebut, panel surya dapat dipasang di atap-atap gedung di area perkotaan sehingga tidak membutuhkan area khusus ${ }^{(8)}$, micro hydro yang memanfaatkan aliran sungai ${ }^{(9)}$, dan turbin angin skala $\operatorname{kecil}^{(7)}$.

Panel surya bekerja dengan menyerap sinar matahari dengan sel fotovoltaik, menghasilkan energi arus searah (DC) dan kemudian mengubahnya menjadi energi arus bolak-balik (AC) yang dapat digunakan dengan bantuan teknologi inverter. Energi yang dihasilkan panel surya bergantung pada parameter iklim atau lingkungan dari wilayah tertentu, seperti intensitas radiasi matahari, kecepatan angin dan kelembaban $^{(10-12)}$. Di area perkotaan, intensitas radiasi matahari bisa dipengaruhi oleh kondisi bangunan yang terhalang baik oleh bangunan sekitar, pohon, juga kabut yang disebabkan polusi(13).

Kecepatan dan arah angin merupakan faktor utama yang menentukan energi yang bisa dihasilkan turbin angin. Turbin angin skala kecil yang dirancang untuk daerah perkotaan, masih menghadapi beberapa tantangan kecepatan angin rendah dengan turbulensi dan perubahan arah angin yang cukup tinggi, kebisingan, dan getaran $^{(14-17)}$.

Sebagai bentuk dukungan terhadap program pemerintah dan salah satu upaya pemenuhan energi listrik mandiri, Universitas Pertamina yang berlokasi di Simprug Jakarta Selatan membangun pembangkit listrik dengan konsep pemanfaatan EBT untuk menghasilkan energi yang dapat menurunkan biaya energi operasional universitas. Pembangkit listrik yang dipilih menggunakan panel surya dan turbin angin $^{(18)}$.

Konsumsi listrik di Universitas Pertamina selama Januari hingga Mei 2018 berkisar di antara 300 - 400 kWh perbulannya untuk mendukung kegiatan belajar-mengajar sebanyak 1413 mahasiswa. Dengan pertambahan mahasiswa di tahun-tahun berikutnya, konsumsi listrik universitas diprediksi akan turut meningkat. Karena itu perancangan mengenai kebutuhan energi menjadi penting dalam tahap perencanaan konstruksi untuk membuat konstruksi yang efisien dalam penggunaan energi atau mengurangi biaya energi. Disamping itu, hasil perbandingan ini bisa menjadi salah satu pertimbangan dalam pemilihan EBT di area perkotaan dengan keadaan geografis dan karakter lingkungan yang serupa.

\subsection{Tujuan Penelitian}

Saat ini sudah banyak penelitian yang membandingkan penggunaan tenaga surya dan tenaga angin sebagai pembangkit listrik alternatif. Namun, perbandingan ini umumnya di lakukan di negara sub-tropis yang keadaan geografisnya berbeda dengan keadaan geografis di Indonesia(19).

Penelitian ini bertujuan menentukan teknologi pembangkit listrik EBT mana yang paling baik untuk digunakan di lingkungan Universitas Pertamina secara khusus serta area perkotaan di wilayah tropis secara umum dengan mempertimbangkan keadaan geografis dan karakteristik area perkotaan. Penelitian ini juga diharapkan dapat menjadi tolok ukur untuk bangunan komersil serupa di lokasi yang memiliki kesamaan karakteristik. Kesesuaian teknologi yang dipakai diukur berdasarkan tingkat kehandalan dan efisiensi yang tinggi, polusi yang rendah, serta dampak lingkungan yang paling rendah.

\section{BAHAN DAN METODE}

\subsection{Lokasi Penelitian}

Implementasi EBT tenaga surya dan angin di dipengaruhi oleh beberapa faktor seperti intensitas radiasi matahari, kecepatan dan arah angin serta kelembaban. Di area perkotaan, ada beberapa faktor tambahan seperti jarak dan ketinggian gedung sekitar serta tingkat polusi. Semua faktor tersebut bergantung pada lokasi penelitian.

Penelitian dilakukan di area Kebayoran Lama, Jakarta Selatan, DKI Jakarta. Keadaan Kota Jakarta umumnya beriklim panas dengan suhu udara maksimum berkisar 32,7 - $34{ }^{\circ} \mathrm{C}$ pada siang hari, dan suhu udara minimum berkisar 23,8 - 25,4 ${ }^{\circ} \mathrm{C}$ pada malam hari. Ratarata curah hujan sepanjang tahun $237,96 \mathrm{~mm}$, tingkat kelembaban udara mencapai 73,0 $78,0 \%$ dan kecepatan angin rata-rata mencapai $2,2-2,5 \mathrm{~m} / \mathrm{s}^{(20)}$.

Secara astronomis Kota Administrasi Jakarta Selatan terletak antara 6 $6^{\circ} 15^{\prime} 40,8^{\prime \prime}$ Lintang Selatan dan $106^{\circ} 45^{\prime} 0,00^{\prime \prime}$ Bujur Timur. Jakarta Selatan merupakan dataran rendah dengan ketinggian rata-rata 26,2 meter diatas permukaan laut ${ }^{(21)}$. Kecepatan angin di area ini berkisar antara 0,60 - 1,13 m/s berdasarkan data tahun 2016 dari stasiun BMKG terdekat (Kemayoran) dan observasi langsung di lapangan pada Gambar 1.

Pengukuran langsung yang dilakukan di bulan September 2017 di lantai 9 gedung Universitas Pertamina menggunakan anemometer menunjukkan data kecepatan angin terendah adalah $0,1 \mathrm{~m} / \mathrm{s}$ (Gambar 1A), kecepatan angin rata-rata sebesar $2,2 \mathrm{~m} / \mathrm{s}$ (Gambar 1B) dan kecepatan angin terbesar mencapai $5,5 \mathrm{~m} / \mathrm{s}$ (Gambar 1C). 

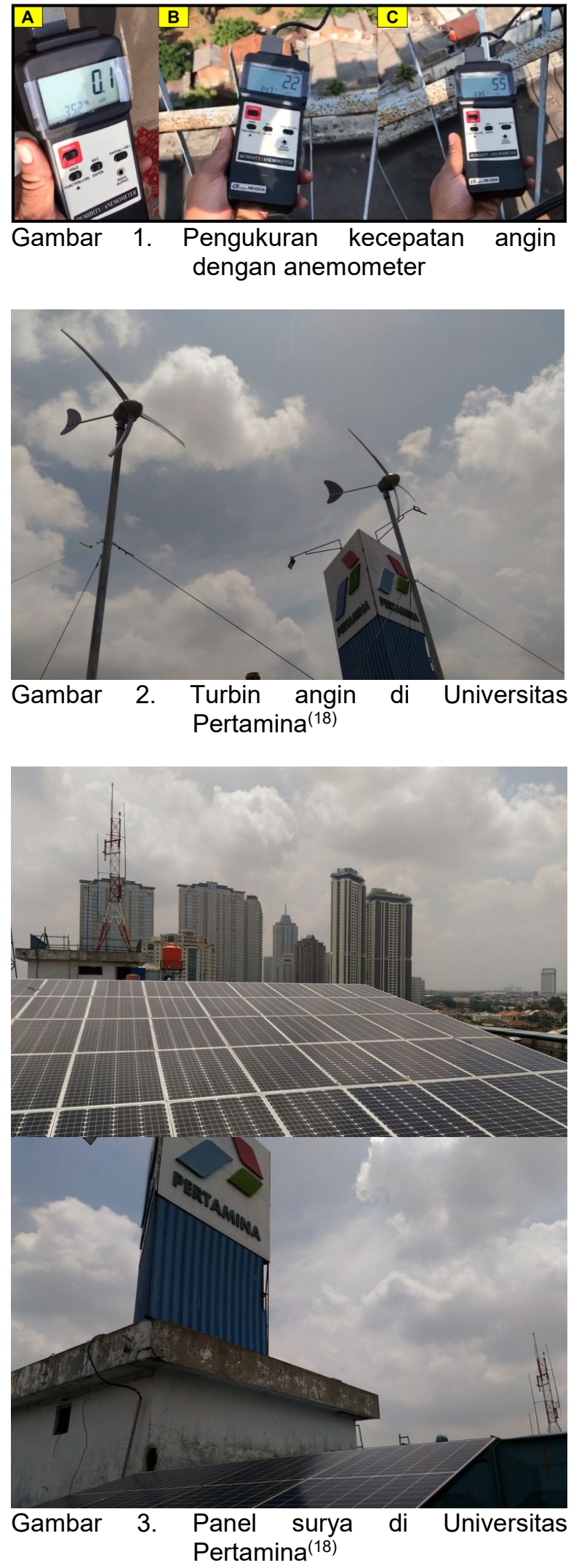

Turbin angin dan panel surya dipasang di atap salah satu gedung Universitas Pertamina (lantai 9) seperti yang ditunjukkan pada Gambar 2. Dua turbin angin merupakan buatan A-WING Internasional model AWI-E1000T(22) dengan radius mesin rotor yang digunakan adalah 2,058 meter berkapasitas 1 kilowatt peak (kWp) per unit dan kapasitas total $2 \mathrm{kWp}$ menggunakan sistem off-grid. Daya yang dihasilkan disimpan ke 4 buah baterai yang masing-masing memiliki kapasitas $1 \mathrm{kWh}$. Setelah baterai penuh daya dialirkan ke beban. Panel surya menggunakan modul surya Monocrystal ASL M200i(23) $200 \mathrm{Wp}$ sebanyak 25 unit seperti yang ditunjukkan pada Gambar 3 dengan metode on-grid yang selalu mengalirkan arus listrik yang didapat dari panel surya. Kapasitasnya 100 watt peak per panel, sehingga dapat menghasilkan $10 \mathrm{~kW}$ per jamnya.

Potensi energi listrik yang bisa dihasilkan panel surya berdasarkan intensitas cahaya matahari dan faktor-faktor penghalang seperti bayangan, debu, dan rugi-rugi dihitung menggunakan Persamaan 1(24). Selanjutnya potensi energi listrik yang dihasilkan turbin angin berdasarkan kecepatan angin, jenis turbin, dan kepadatan udara dihitung dengan Persamaan $2^{(25)}$ dimana kepadatan udara dihitung berdasarkan suhu dan tekanan udara seperti dituliskan pada Persamaan $3^{(26) \text {. }}$

$E=(k W p \times s s \times P R) / 1000$

Keterangan:

$\mathrm{E}=$ Energi yang dihasilkan ( $\mathrm{kWh})$

$A=$ daya listrik per panel surya $(\mathrm{kWp})$

Ss $=$ rata-rata lama penyinaran matahari (jam)

$\mathrm{PR}=$ Performance Ratio (antara 0,5-0,9 dengan nilai default 0,75 )

$P=\pi / 2 \times r^{2} \times V^{3} \times \rho \times \eta$.

Keterangan:

$\mathrm{P}=$ Energi yang dihasilkan (kWh)

$r=$ radius rotor(meter)

$V=$ kecepatan angin $(\mathrm{m} / \mathrm{s})$

$\rho=$ kepadatan udara $\left(\mathrm{kg} / \mathrm{m}^{3}\right)$

$\eta=$ faktor efisiensi $(\%)$

$\rho=P / R \times T$.

Keterangan:

$\rho=$ kepadatan udara $(\mathrm{kg} / \mathrm{m} 3)$

$\mathrm{P}=$ tekanan udara(meter)

$\mathrm{R}=$ konstanta gas $(0,167226 \mathrm{~J} / \mathrm{kg} \mathrm{K})$

$\mathrm{T}=$ suhu udara (Kelvin)

\subsection{Perhitungan Optimasi}

Setelah mengetahui potensi energi yang dihasilkan pada lokasi tertentu, dilakukan perbandingan lebih lanjut dalam aspek ekonomi, kehandalan dan lingkungan. Metode yang digunakan dalam penelitian ini adalah studi pustaka dan analisis kuantitatif. Studi pustaka dilakukan berdasarkan penggunaan tenaga surya dan angin di negara maju. Analisis kuantitatif dilakukan berdasarkan pengamatan penggunaan pembangkit listrik tenaga surya dan angin di Universitas Pertamina. 
Berdasarkan studi literatur, penelitian ini akan memperhatikan aspek efisiensi ekonomi, kehandalan, dan dampak lingkungan dari kedua pembangkit listrik ini.

Efisiensi ekonomi dilakukan dengan membandingkan biaya instalasi dan biaya operasional dengan biaya penggunaan listrik yang berhasil dihemat. Persamaan 4 digunakan untuk menghitung biaya instalasi. Untuk menghitung Payback Period, kapan penggunaan teknologi pembangkit listrik ini akan menutup biaya instalasi atau investasi awal dihitung menggunakan Persamaan 5 . Selain kedua hal tersebut, diukur juga biaya listrik PLN yang berhasil dikurangi karena penggunaan energi terbarukan ini menggunakan Persamaan 6.

$\mathrm{A}=(\mathrm{I}+\mathrm{M}) / \mathrm{O}$

Keterangan:

$A=$ Nilai investasi

$\mathrm{O}=$ Output dari Pembangkit Listrik

I = Besarnya investasi awal

$\mathrm{M}=$ Biaya Pemeliharaan

$Y=(I+M) / E$

Keterangan:

$\mathrm{Y}=$ Payback Period (dalam tahun)

$\mathrm{I}$ = Besarnya investasi awal

$\mathrm{M}=$ Biaya Pemeliharaan

$\mathrm{E}=$ Efisiensi dari penggunaan teknologi EBT per tahun

$E B=O * P$

Keterangan:

$\mathrm{EB}=$ Biaya Listrik yang berhasil dihemat/dikurangi

$\mathrm{O}=$ Output yang dihasilkan

$\mathrm{P}=$ Biaya Listrik per kWh dari PT. PLN

Kehandalan diukur dari seberapa sering masing-masing teknologi ini mengalami kegagalan dalam kurun waktu yang sama. Dampak lingkungan diukur dengan membandingkan berapa emisi karbon yang yang dikurangi oleh masing-masing pembangkit listrik. Masing-masing pembangkit listrik akan dibandingkan emisi karbonnya jika daya yang sama dihasilkan dengan pembangkit listrik berbahan bakar fosil. Pengurangan emisi karbon antara kedua pembangkit ini kemudian akan dibandingkan untuk mencari pembangkit yang mengurangi emisi karbon terbesar. Selain emisi karbon, juga dibandingkan bentuk polusi lain seperti polusi suara. Untuk menghitung emisi karbon digunakan Persamaan $7^{(27)}$. Karena satuan yang dibaca dari pembangkit listrik dalam kWh, kita perlu melakukan konversi satuan kedalam BTU seperti dijelaskan pada Persamaan $8^{(28)}$.
$\mathrm{CE}=\mathrm{O} * \mathrm{f}$

Keterangan:

$\mathrm{CE}=$ Emisi Karbon

$\mathrm{O}=$ Output dari Pembangkit Listrik dalam BTUs

$\mathrm{f}=$ Emission Factor

$\mathrm{CE}=\mathrm{O}{ }^{*} \mathrm{BTU}{ }^{*} \mathrm{~T}$

Keterangan:

$\mathrm{CE}=$ Emisi Karbon

$\mathrm{O}=$ Output dari Pembangkit Listrik dalam kWh

BTU = Konstansta 1 British Thermal Units (BTUs)

$\mathrm{T}=$ Jumlah $\mathrm{CO}_{2}$ yang dihasilkan dalam Pound

Untuk menyimpulkan teknologi mana yang paling efisien untuk digunakan di lingkungan Universitas Pertamina, digunakan teknik Kepner-Tregoe Decision Analysis (KTDA). Dengan menggunakan KTDA, akan dibuat tabulasi untuk menampilkan beberapa parameter penilaian yang dibutuhkan dan mengevaluasi pemenuhan setiap alternatif solusi terhadap parameter tersebut. Untuk setiap alternatif diberikan bobot (tingkat kepentingan) dan rating (tingkat pemenuhan). Untuk mendapatkan skor akhir dari masingmasing pilihan, bobot dikalikan dengan rating. Keputusan diambil berdasarkan pilihan dengan skor tertinggi(29).

\section{HASIL DAN PEMBAHASAN}

\subsection{Aspek Iklim dan Kondisi Geografis}

Iklim dan kondisi geografis lokasi penelitian diukur dari 2 stasiun meteorologi terdekat, yakni Stasiun Kemayoran di Jl. Angkasa I No. 2, Kemayoran, Jakarta Pusat dengan elevasi 4 yang berjarak sekitar $13,8 \mathrm{~km}$ dari lokasi penelitian, dan Stasiun Tangerang Selatan di JI. Raya Kodam Bintaro No 82 Jakarta Selatan dengan elevasi 27 , sekitar $5,5 \mathrm{~km}$ dari lokasi penelitian. Data iklim yang berpengaruh terhadap performansi panel surya dan turbin angin adalah intensitas radiasi matahari dan kecepatan angin ${ }^{(30)}$.

Data iklim dirangkum dari data harian iklim sepanjang tahun 2018 dari situs data online BMKG $^{(31)}$ seperti ditunjukkan pada Gambar 4 hingga Gambar 7. Intensitas radiasi matahari di area Jakarta Selatan seperti yang ditunjukkan pada Gambar 5 sedikit lebih rendah dibandingkan intensitas radiasi matahari di area Jakarta Pusat pada Gambar 4, sebanyak 4,6 jam di Jakarta Pusat dan 4,2 jam di Jakarta Selatan. Berdasarkan kondisi geografis dan iklim yang didapatkan dari data BMKG dengan lama penyinaran matahari rata-rata $4,01 \mathrm{~m} / \mathrm{s}$ dan berdasarkan daya listrik $0,2 \mathrm{kWp}$ serta performance ratio default sebesar 0,75 dengan mengikuti Persamaan 1 diperoleh potensi energi output sebesar $15,0375 \mathrm{kWh}$. 


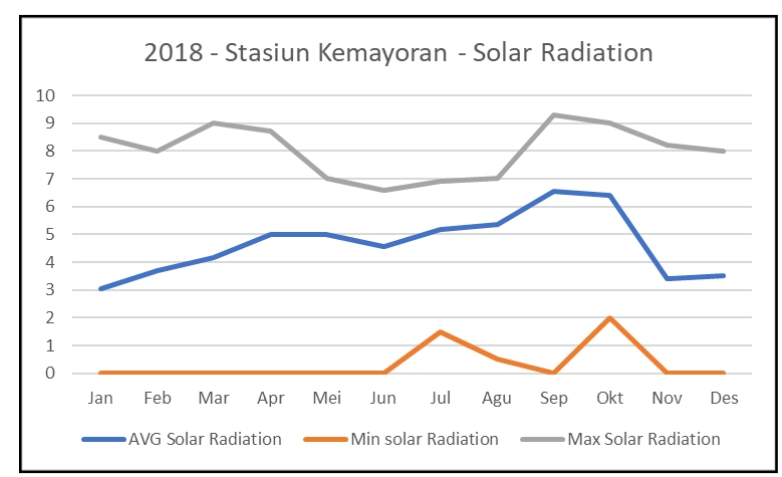

Gambar 4. Data intensitas radiasi matahari tahun 2018 stasiun pencatatan Kemayoran

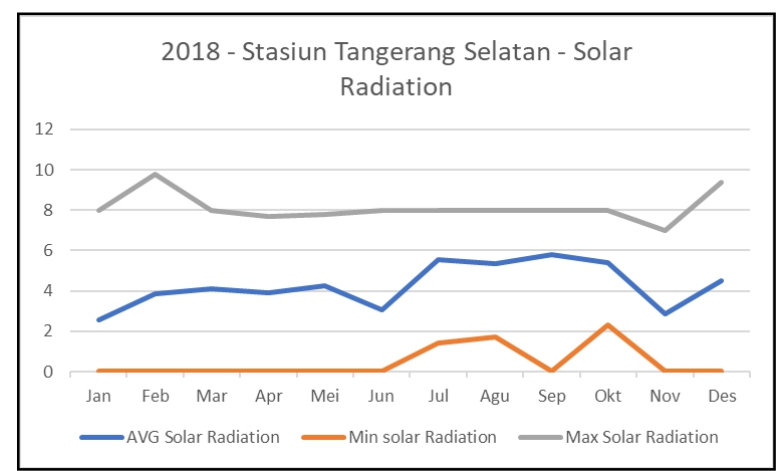

Gambar 5. Data intensitas radiasi matahari tahun 2018 stasiun pencatatan Tangerang Selatan

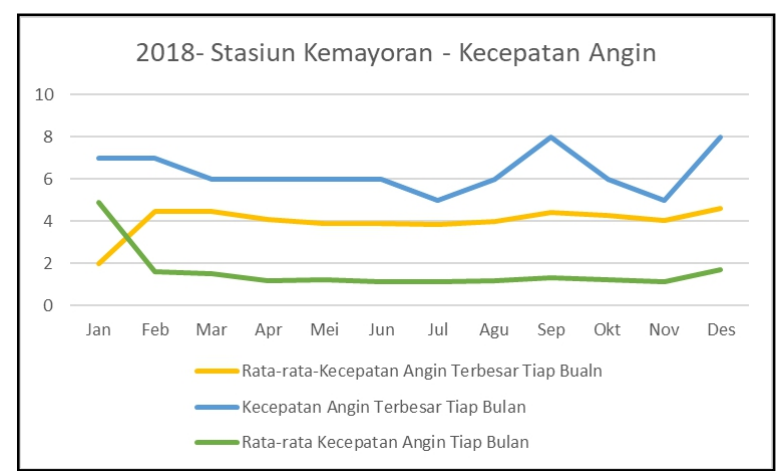

Gambar 6. Data kecepatan angin tahun 2018 stasiun pencatatan Kemayoran

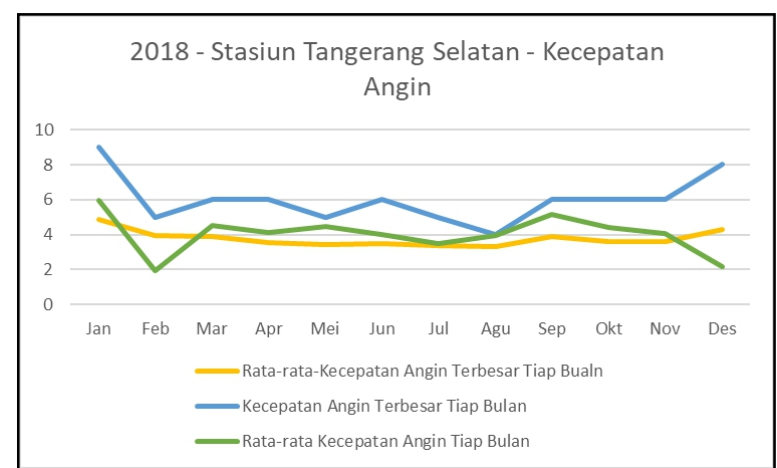

Gambar 7. Data kecepatan angin tahun 2018 stasiun pencatatan Tangerang
Kepadatan udara dapat dihitung dengan Persamaan 3 berdarkan data suhu, kelembaban, dan tekanan udara. Namun data tekanan udara tidak tersedia di situs BMKG, sehingga dalam penelitian ini digunakan nilai $1,2 \mathrm{~kg} / \mathrm{m}^{3}$ sebagai nilai kepadatan udara ${ }^{(25)}$. Kecepatan angin ratarata bulanan di Jakarta Selatan (rata-rata 4,01 $\mathrm{m} / \mathrm{s}$ per tahun) lebih tinggi dibandingkan Jakarta Pusat (rata-rata $1,59 \mathrm{~m} / \mathrm{s}$ per tahun) seperti yang ditunjukkan pada Gambar 6 dan 7 . Gambar 7 juga menunjukkan bahwa kecepatan angin di area Jakarta Selatan cenderung lebih stabil. Perbedaan hasil pengukuran ini mungkin disebabkan karena perbedaan elevasi kedua stasiun meteorologi. Gesekan massa udara yang bergerak terhadap permukaan bumi memperlambat kecepatan angin, sehingga kecepatan angin akan meningkat seiring dengan ketinggian $^{(7)}$. Karena itu untuk perkiraan energi output dari turbin angin akan digunakan kecepatan angin dari stasiun Tangerang Selatan. Dengan ukuran diameter mesin rotor 2,058 meter dan faktor efisiensi sebesar $40 \%$, diperoleh perkiraan daya yang dihasilkan turbin angin sebesar 0,206 $\mathrm{kW}$ atau energi sebesar 0,206 kWh. Jika diasumsikan kecepatan angin sepanjang hari stabil, potensi energi output per hari adalah 4,944 $\mathrm{kWh}$.

\subsection{Aspek Ekonomi}

Aspek ekonomi diukur dari dua hal; pertama berdasarkan perbandingan nilai investasi awal, kedua berdasarkan besarnya biaya tagihan listrik yang berhasil dikurangi karena asupan daya dari kedua pembangkit listrik ini dan lamanya pengembalian nilai investasi.

Untuk menghitung nilai invetasi, digunakan Persamaan 4 yang membagi biaya instalasi pada Tabel 1 dengan nilai output tahunan pada Tabel 2. Biaya perawatan diabaikan dalam perhitungan ini karena kedua pembangkit ini masih dalam periode garansi. Hasil perhitungan ditampilkan pada Tabel 3.

Tabel 1. Biaya pemasangan pembangkit listrik

\begin{tabular}{ccl}
\hline Teknologi & Biaya Instalasi & Kapasitas \\
\hline Panel surya & Rp. 250.000.000,- & $10 \mathrm{kWp}$ \\
Turbin angin & Rp. 297.000.000,- & $2 \mathrm{kWp}$ \\
\hline
\end{tabular}

Tabel 2. Data output

\begin{tabular}{lcc}
\hline Teknologi & $\begin{array}{c}\text { Output per } \\
\text { bulan }\end{array}$ & $\begin{array}{c}\text { Output } \\
\text { (1 tahun) }\end{array}$ \\
\hline Panel surya & $1.066,83 \mathrm{~kW}$ & $12.802 \mathrm{kWh}$ \\
Turbin angin & $1.085,56 \mathrm{~kW}$ & $53,11 \mathrm{kWh}$ \\
\hline
\end{tabular}


Tabel 3. Nilai Investasi

\begin{tabular}{ll}
\hline Teknologi & Nilai Investasi \\
\hline Panel surya & Rp. 19.528,- /kW \\
Turbin angin & Rp. 22.799,-/kW \\
\hline
\end{tabular}

Listrik yang dihasilkan dalam 1 tahun untuk panel surya adalah $12,802 \mathrm{MWh}$, sedangkan untuk turbin angin adalah $53 \mathrm{kWh}$. Output tahunan dari kedua pembangkit sangat timpang karena turbin angin hanya bekerja selama 2 bulan akibat kerusakan baterai. Karena kerusakan ini, untuk analisis selanjutnya output tahunan untuk turbin angin menggunakan asumsi output 1 bulan sebagai nilai rata-rata, sehingga output tahunan untuk turbin angin adalah $1.085,56 \mathrm{~kW} * 12$ bulan $=13.026,72 \mathrm{~kW}$

Listrik yang dihasilkan digunakan sebagai sumber penerangan ruang perpustakaan yang terletak di lantai 8 Gedung Griya Legita sebesar 1205 Wh. Ruangan ini menggunakan listrik dari pembangkit listrik EBT selama 4 jam atau kurang dalam sehari sehingga mengurangi penggunaan listrik yang disediakan oleh PT. PLN. Tabel 4 memperhitungkan besarnya penghematan yang berhasil dicapai masingmasing pembangkit listrik dengan mengasumsikan tarif listrik sebesar Rp 1.467,8/kWh menggunakan Persamaan 6.

Tabel 4. Nilai penghematan tagihan listrik per bulan

\begin{tabular}{cr} 
Teknologi & Jumlah Tagihan yang Dihemat \\
\hline Panel surya & Rp. $18.790 .755,6$ \\
Turbin angin & Rp. $19.120 .619,6$ \\
\hline
\end{tabular}

Berdasarkan jumlah penghematan per bulan pada Tabel 4, dapat dihitung berapa lama investasi awal akan dapat tertutup menggunakan Persamaan 6 seperti yang ditunjukkan pada Tabel 5.

Tabel 5. Payback period

\begin{tabular}{cc}
\hline Teknologi & Payback Periode \\
\hline Panel surya & $\begin{array}{c}250.000 .000 / 18.790 .755,6=13,3 \\
\text { tahun }\end{array}$ \\
Turbin angin & $\begin{array}{c}297.000 .000 / 19.120 .619,6=15,5 \\
\text { tahun }\end{array}$ \\
\hline
\end{tabular}

Berdasarkan aspek ekonomi, panel surya lebih efisien dibandingkan turbin angin. Walaupun turbin angin memiliki potensi penghematan biaya listrik lebih tinggi, nilai investasi awal turbin angin lebih mahal dibanding panel surya sehingga nilai investasi lebih tinggi dan periode pengembalian nilai investasi tersebut lebih lama.

\subsection{Aspek Instalasi dan Pemeliharaan}

Berdasarkan studi literatur, selama panel surya beroperasi, tidak ada biaya yang harus dikeluarkan untuk maintenance dan replacement karena umur dari panel surya secara teknis bisa mencapai 25 tahun dan cara maintenance-nya itu hanya perlu dilap dan dibersihkan saja ${ }^{(32)}$. Untuk turbin angin, karena memiliki komponen yang bergerak perlu dilakukan pemeliharaan rutin seperti perawatan bilah turbin, rotor dan komponen lain untuk meminimalisir getaran pada turbin ${ }^{(33-35)}$.

Di Universitas Pertamina, kedua pembangkit listrik dipasang di lokasi yang sama, lantai 9 Gedung Griya Legita seperti pada Gambar 2 dan Gambar 3. Proses instalasi kedua jenis pembangkit listrik ini relatif sama yakni selama 1 minggu. Pembangkit listrik mulai digunakan di bulan Januari 2018.

Hingga Desember 2018, panel surya belum pernah dilakukan pemeliharaan dan tidak pernah mengalami kerusakan sedangkan turbin angin mengalami kerusakan baterai di pertengahan bulan Februari 2018 dan belum berjalan hingga Desember 2018 saat data diambil. Karena penggunaan masih dibawah satu tahun, perbaikan untuk kerusakan ini tidak dikenakan biaya.

\subsection{Aspek Lingkungan}

Di Indonesia pembangkit listrik didominasi Pembangkit Listrik Uap yang berbahan batubara (48\%), Pembangkit Listrik Tenaga Gas dan Uap yang berbahan bakar gas (22\%) dan Pembangkit Listrik Tenaga Diesel yang berbahan bakar diesel $(11 \%)^{(10,11)}$. Oleh karena itu penghematan emisi dihitung menggunakan Persamaan 7 dan 8 untuk ketiga jenis bahan bakar tersebut. Tabel 6 menunjukkan koefisien emisi $\mathrm{CO}_{2}$ untuk masing-masing bahan bakar.

Tabel 6. Koefisien emisi $\mathrm{CO}_{2}{ }^{(38)}$

\begin{tabular}{|c|c|}
\hline Bahan Bakar & $\begin{array}{l}\text { Emisi } \mathrm{CO}_{2} \text { yang dihasilkan } \\
\text { (Kg CO}{ }_{2} \text { Per Million BTUs*) }\end{array}$ \\
\hline Batubara & 95,35 \\
\hline Gas & 53,07 \\
\hline Solar & 73,16 \\
\hline
\end{tabular}

Berdasarkan hasil perhitungan di Tabel 7 , jumlah emisi karbon yang berhasil diturunkan 
kurang lebih sama antara kedua teknologi pembangkit listrik.

Tabel 7. Pengurangan emisi $\mathrm{CO}_{2}$

\begin{tabular}{lcc}
\hline Bahan Bakar & $\begin{array}{c}\text { Panel Surya } \\
(\mathbf{k g})\end{array}$ & $\begin{array}{c}\text { Turbin Angin } \\
(\mathbf{k g})\end{array}$ \\
\hline Batubara & 4.166 .149 .099 & 4.239 .279 .627 \\
Gas & 2.318 .799 .503 & 2.359 .502 .567 \\
Solar & 3.196 .596 .414 & 3.252 .707 .892 \\
\hline
\end{tabular}

Selain emisi karbon, masing-masing pembangkit listrik memiliki dampak lain terhadap lingkungan seperti polusi suara yang ditimbulkan oleh turbin angin ${ }^{(39,40)}$. Pembangikt listrik di Universitas Pertamina hanya menggunakan 2 turbin angin, polusi suara ini tidak terlalu dirasakan. Jika akan menambah jumlah turbin angin, polusi suara perlu diperhatikan agar tidak mengganggu pengguna gedung perkuliahan. Turbin angin juga memiliki dampak ekologi, karena harus dipasang di tempat cukup tinggi untuk mendapatkan kecepatan angin yang memadai, putaran bilah atau baling-baling dapat melukai bahkan membunuh hewan seperti burung atau kelelawar ${ }^{(39,41)}$. Sejauh ini, belum pernah ada hewan yang terluka atau mati di area Universitas Pertamina akibat bilah turbin angin.

Panel surya dapat membahayakan lalu lintas udara akibat sinar yang tidak sepenuhnya terserap dipantulkan ke atas. Sinar yang panas ini juga dapat mengganggu ekosistem karena dapat membunuh hewan yang melintas diatasnya ${ }^{(42)}$. Lokasi Universitas Pertamina yang tidak berada di lintasan pesawat udara membuat dampak ini tidak relevan untuk dipertimbangkan. Sama seperti turbin angin tidak pernah ditemukan hewan yang terluka atau mati disekitar lokasi panel surya selama ini.

\subsection{Analisis Pemilihan}

Untuk memilih teknologi yang paling efektif dan efisien tidak hanya diperhitungkan faktor ekonomis saja tetapi juga faktor lain seperti yang disebutkan di Tabel 9. Mengikuti metode kepner-tregoe decision analysis, setiap faktor diberi bobot berdasarkan klasifikasi tertentu. Klasifikasi bobot dapat dilihat di Tabel 8 . Penilaian tingkat pemenuhan terhadap masingmasing faktor dikuantifikasi berdasarkan klasifikasi rating yang ada di Tabel 8. Hasil perkalian antara bobot dan rating menunjukkan skor atau nilai untuk setiap faktor. Pemilihan teknologi ditentukan berdasarkan jumlah skor dari semua faktor yang terbesar.
Tabel 8. Klasifikasi angka bobot dan angka rating

\begin{tabular}{lcc}
\hline Nilai & Bobot & Rating \\
\hline $1-2$ & Cenderung Tidak Penting & Sangat Kurang \\
$3-4$ & Kurang Penting & Kurang \\
$5-6$ & Cukup & Cukup \\
$7-8$ & Penting & Baik \\
$9-10$ & Sangat Penting & Sangat Baik \\
\hline
\end{tabular}

Tabel 9. Evaluasi penggunaan panel surya dan turbin angin sebagai pembangkit listrik

Panel Surya Turbin Angin

\begin{tabular}{lccccc} 
Parameter & Bobot & Rating & Skor & Rating & Skor \\
\hline Biaya Instalasi & 6 & 6 & 36 & 5 & 30 \\
$\begin{array}{l}\text { Penghematan } \\
\text { Biaya Listrik }\end{array}$ & 8 & 6 & 48 & 5 & 40 \\
Kehandalan & 5 & 9 & 45 & 5 & 25 \\
$\begin{array}{l}\text { Pengurangan } \\
\text { Emisi Karbon }\end{array}$ & 8 & 6 & 48 & 6 & 48 \\
$\begin{array}{l}\text { Dampak Lain } \\
\text { Total }\end{array}$ & 2 & 9 & 18 & 9 & 18 \\
\hline
\end{tabular}

Penilaian rating ditentukan berdasarkan perhitungan yang sudah dilakukan di bagian hasil dan perhitungan dan melalui analisis penilaian teknikal dari pengamatan terhadap panel surya dan turbin angin selama satu tahun. Berdasarkan hasil perhitungan menunjukkan bahwa panel surya memiliki nilai yang lebih tinggi yang artinya lebih baik dibanding turbin angin dalam hal efisiensi dan efektivitas.

\section{KESIMPULAN}

Instalasi panel surya dan turbin angin skala kecil di area perkotaan diharapkan dapat mendorong tercapainya target pemerintah untuk menerapkan EBT sebesar $25 \%$ pada tahun 2025. Perbandingan sumber EBT yang dapat menghasilkan energi paling optimal di area perkotaan perlu dilakukan agar upaya ini bisa maksimal. Dengan membandingkan potensi energi, aspek ekonomi, kemudahan pemeliharaan dan dampak lingkungan dari kedua pembangkit yang memanfaatkan EBT tersebut didapatkan bahwa pembangkit listrik tenaga surya lebih optimal untuk diterapkan di area Universitas Pertamina dan di wilayah perkotaan dimana lokasi instalasi tidak terhalang baik oleh bangunan ataupun objek lain seperti pohon. Pada sampel Universitas Pertamina, efisiensi panel surya jauh lebih baik karena tingginya frekuensi kerusakan baterai pada turbin angin. Ketidaklengkapan data dan ketidaksetaraan ini menurunkan tingkat 
keakuratan perbandingan antara kedua jenis pembangkit listrik ini. Penelitian selanjutnya dapat dilakukan dengan menambahkan data sudut pemasangan panel surya dan data kepadatan udara untuk turbin angin. Metode simulasi dengan data historis per jam untuk membandingkan efisiensi kedua pembangkit ini juga memiliki potensi untuk menghasilkan perhitungan yang lebih akurat.

\section{DAFTAR PUSTAKA}

1. Sekretaris Jenderal Dewan Energi Nasional. (2016). Outlook Energi indonesia 2016.

2. Primadhyta, S. (2018). Terjerat di Lingkaran Setan Proyek Energi Terbarukan. Retrieved from

https://www.cnnindonesia.com/ekonomi/2018 0125115623-85-271472/terjerat-di-lingkaransetan-proyek-energi-terbarukan [1 Juni 2020]

3. Geem, Z. W., Kim, J. H. (2016). Optimal energy mix with renewable portfolio standards in Korea. Sustain, 8(5), 1-14.

4. Shmelev, S. E., Van Den Bergh, J. C. J. M. (2016). Optimal diversity of renewable energy alternatives under multiple criteria: An application to the UK. Renewable and Sustainable Energy Reviews, 60, 679-691.

5. Dang, M. (2013). Potential of Solar Energy in Tropics. International Journal of Engineering Science and Technology, 5(7), 1413-1418.

6. Zakiah, N. (2019). 7 Alasan Indonesia Tak Gunakan Pembangkit Listrik Tenaga Surya. Retrieved from

https://kaltim.idntimes.com/tech/trend/nenazakiah-1/alasan-indonesia-tidakmenggunakan-pembangkit-listrik-tenagasurya-sebagai-sumber-energi-utama-regionalkaltim/7 [1 Juni 2020]

7. Satwika, N. A., Hantoro, R., Septyaningrum, E. , Mahmashani, A. W. (2019). Analysis of wind energy potential and wind energy development to evaluate performance of wind turbine installation in Bali, Indonesia. Journal of Mechanical Engineering and Sciences, 13(1), 4461-4476.

8. Sea, P. (2019). Harnessing Indonesia's Solar Potential: Yellow is The New Black - IESR. Retrieved from http://iesr.or.id/harnessingindonesias-solar-potential-yellow-is-the-newblack/ [1 Juni 2020]

9. Erinofiardi, Gokhale, P., Date, A., Akbarzadeh, A., Bismantolo, P., Suryono, A., Mainil, A., Nuramal, A. (2017). A Review on Micro Hydropower in Indonesia. Energy Procedia, 110, 316-321.
10. Ogbomo, O. O., Amalu, E. H., Ekere, N. N., Olagbegi, P. O. (2017). A review of photovoltaic module technologies for increased performance in tropical climate, Renewable and Sustainable Energy Reviews, $75,1225-1238$.

11.Schweiger, M., Herrmann, W., Gerber, A., Rau, U. (2017). Understanding the energy yield of photovoltaic modules in different climates by linear performance loss analysis of the module performance ratio. IET Renewable Power Generation, 11(5), 558565.

12. Dierauf, T., Growitz, A., Kurtz, S., Cruz, J. L. B., Riley, E., Hansen, C. (2013). WeatherCorrected Performance Ratio. National Renewable Energy Laboratory.

13. Lobaccaro, G., Frontini, F. (2014). Solar energy in urban environment: how urban densification affects existing buildings. Energy Procedia, 48(1876), 1559-1569.

14. Roothaan, S., Williams, C., Guerrero, S., Acioli, P. (2012). Optimization of Small Scale Wind Turbine in Urban Areas. Paper Presented at 2012 Society for Advancement of Hispanics/Chicanos and Native Americans in Science National Conference.

15. Grauthoff, M. (1991). Utilization of wind energy in urban areas - Chance or utopian dream? . Energy and Buildinf, 16(1-2), 517523.

16. Lu, L., Ip, K. Y. (2009). Investigation on the feasibility and enhancement methods of wind power utilization in high-rise buildings of Hong Kong. Renewable and Sustainable Energy Reviews, 13(2), 450-461.

17.Bahaj, A. S., Myers, L., James, P. A. B. (2007) Urban energy generation: Influence of microwind turbine output on electricity consumption in buildings. Energy and Buildings, 39(2), 154-165.

18.Budi, K, (2018). Perguruan Tinggi Diajak Kembangkan Renewal Energy. Retrieved from

https://edukasi.kompas.com/read/2018/02/02/ 15000031/perguruan-tinggi-diajakkembangkan-renewal-energy [17 Mei 2019]

19. The International Renewable Energy Agency. (2016). Cities, towns \& renewable energy: Yes in my front yard.

20. Portal Resmi Provinsi DKI Jakarta. (2008). Geografis Jakarta | Portal Resmi Pemerintah Provinsi DKI Jakarta. Retrieved from https://jakarta.go.id/artikel/konten/55/geografis -jakarta [1 Juni 2020] 
21. Badan Pusat Statistik Kota Administrasi Jakarta Selatan. (2020). Kota Administrasi Jakarta Selatan Dalam Angka 2020.

22. A-Wing International. (Tuesday, 2 Jun 2020). AWI-E1000T - A-Wing International Small Wind Turbines. Retrieved from http://www.awing-

i.com/english/1kW_wind_turbine.html\#

23. Azet Surya Lestari. (Friday, 17 May 2019). Monocrystal ASL M5-200 V2016.05.08, Retrieved from http://www.azetsurya.id/pageprod-modulsurya-detail.php\#

24. Vivint Solar Learning Center. (Wednesday, 3 Jun 2020). How to Calculate Solar Panel Output. Retrieved from https://www.vivintsolar.com/learningcenter/how-calculate-solar-panel-output

25. Kummer, J. (Tuesday, 2 Jun 2020). Wind Turbine Power Calculator. Retrieved from https://rechneronline.de/wind-power/

26. Kummer, J. (Tuesday, 2 Jun 2020). Air density calculator. Retrieved from https://rechneronline.de/barometer/luftdichte.p hp

27. Carbon Fund. (Thursday, 16 May 2019). How We Calculate. Retrieved from https://carbonfund.org/how-we-calculate/

28.U.S. Energy Information Administration. (Thursday, 16 May 2019). How much carbon dioxide is produced when different fuels are burned?. $\quad$ Retrieved from https://www.eia.gov/tools/faqs/faq.php?id=73\& $\mathrm{t}=11$

29. Fogler, H. S., Steven, E. L., Rizzo, B. (2013). Strategies for Creative Problem Solving 3rd Edition: Prentice Hall.

30. El-Ali, A., Moubayed, N., Outbib, R. (2007). Comparison between solar and wind energy in Lebanon. Paper Presented 9th International Conference on Electrical Power Quality and Utilisation.

31. Badan Meteorologi Klimatologi dan Geofisika. (Tuesday, 2 Jun 2020). DATA ONLINE PUSAT DATABASE - BMKG. Retrieved from http://dataonline.bmkg.go.id/data_iklim

32. Sutianto, F. B. (2016). Awet 25 Tahun, Panel Surya Tak Perlu Ongkos Perawatan. Retrieved from https://finance.detik.com/energi/d3132787/awet-25-tahun-panel-surya-takperlu-ongkos-perawatan [17 Mei 2019]
33. Rivaldhi, Y., Nasirudin, A. (2012). Analisa Teknis dan Ekonomis Pemasangan Wind Turbine Sebagai Penghasil daya untuk Sistem Penerangan Pada Kapal Tanker 6500 DWT. Retrieved from http://digilib.its.ac.id/public/ITS-paper-198974107100066-Paper.pdf [17 Mei 2019]

34. Vibrasindo, (Friday, 17 May 2019). Perawatan Secara Rutin Meminimalisir Getaran Pada Turbin. Retrieved from http://www.vibrasindo.com/blogvibrasi/detail/1 30/perawatan-secara-rutin-meminimalisirgetaran-pada-turbin

35. Milborrow, D., (2010). Breaking down the cost of wind turbine maintenance | Windpower Monthly. Retrieved from https://www.windpowermonthly.com/article/10 10136/breaking-down-cost-wind-turbinemaintenance [17 Mei 2019]

36.Zuhri, S. (2018). Inilah Kondisi Kelistrikan di Indonesia Saat Ini - Ekonomi Bisnis.com. Retrieved from https://ekonomi.bisnis.com/read/20180130/44/ 731989/inilah-kondisi-kelistrikan-di-indonesiasaat-ini- [17 Mei 2019]

37. Direktorat Jenderal Ketenagalistrikan Kementrian Energi dan Sumber Daya Mineral. (2017), Statistik Ketenagalistrikan 2017.

38.U.S. Energy Information Administration. (2016). Carbon Dioxide Emissions Coeffients. Retrieved from https://www.eia.gov/environment/emissions/co 2_vol_mass.php [17 Mei 2019]

39. Redlitz, H. (2016). The Pros And Cons Of Wind And Solar Energy. Retrieved from https://greenfuture.io/solar/wind-vs-solarenergy/ [17 Mei 2019]

40.Wahyuni, S. (Friday, 17 May 2019) Pembangkit Listrik Tenaga Angin. Retrieved from

https://www.academia.edu/7806434/l._PEMB ANGKIT_LISTRIK_TENAGA_ANGIN

41. Sasongko, F. (2009). Dampak Lingkungan Pembangkit Listrik Tenaga Angin | Konversi ITB," 2009. Retrieved from https://konversi.wordpress.com/2009/03/01/da mpak-lingkungan-pembangkit-listrik-tenagaangin/ [17 Mei 2019]

42. Oey, I. K. W. (2016). Dampak Negatif Panel Surya Terhadap Lingkungan. Retrieved from http://perceptionistheasnwer.blogspot.com/20 16/12/dampak-negatif-panel-suryaterhadap.html 